\title{
ANTIOXIDANT ASSAY OF DAYAK ONION (Eleutherine palmifolia) VIA DPPH (1,1-Difenil-2-Pikrilhidrazil) AND BSLT TEST FOR ITS ACTIVE FRACTION
}

\author{
Supomo $^{1, *}$, E. S. Syamsul ${ }^{1}$, A. Apriliana ${ }^{1}$, C. Saleh ${ }^{2}$, Erwin $^{2}$ and D. Lestari ${ }^{3}$ \\ ${ }^{1}$ STIKES Samarinda,Samarinda, East Kalimantan, Indonesia \\ ${ }^{2}$ Department of Chemistry, Faculty of Mathematics and Natural Sciences, Universitas \\ Mulawarman, Samarinda 75119, East Kalimantan, Indonesia \\ ${ }^{3}$ Chemistry Postgraduate School, Faculty of Mathematics and Natural Sciences, Universitas \\ Mulawarman, Samarinda 75119, East Kalimantan, Indonesia \\ *E-mail: fahmipomo@gmail.com
}

\begin{abstract}
Dayak Onion (Eleutherine palmifolia) is a widely available plant in Kalimantan which has never been optimally analyzed for its significant. The aim of this research was to determine the active fraction of Dayak Onion (Eleutherine palmifolia) which possesses antioxidant activity. Antioxidant testing was carried out quantitatively with 5 test preparations namely: total ethanol extract, n-hexane fraction, chloroform fraction, ethyl acetate fraction, and ethanol fraction, were carried out using UV-Visible spectrophotometry through DPPH reagent to obtain IC50 Inhibition concentration. The test data results were processed with descriptive analysis. Furthermore, active fraction selected Brine Shrimp Lethality Test (BSLT) was carried out to determine the value of lethal concentration LC50 on shrimp larvae to see the toxicity category. The results showed that the chloroform fraction was an active fraction which had an IC50 of 20.29 ppm (very high category) which was active fraction h. BSLT Test Chloroform fraction has an LC50 value of 527.229 (medium category). In conclusion, Dayak Onion (Eleutherinepalmifolia) which can be widely found in East Kalimantan, Indonesia, is a powerful plant to be an alternative of antioxidant sources.

Keywords: Antioxidant Assay, Active Fraction, Eleutherine palmifolia, DPPH, BSLT Test
\end{abstract}

(C) RASĀYAN. All rights reserved

\section{INTRODUCTION}

Antioxidants play an important role to maintain health. This is caused by the ability of antioxidants to capture free radicals. ${ }^{1-3}$ Free radicals can be produced by the body naturally for example in the respiratory process. Free radicals can be interpreted as chemical molecules that lack electrons or do not have pairs of electrons. This makes free radicals very reactive to look for electron pairs so that the configuration is stable. Free radicals consist of various types of reactive oxygen species that are capable of attacking lipid membranes, nucleic acids, proteins and enzymes. ${ }^{4}$ This can destroy the structure of body cells and change the size and shape. Damage to these cells ultimately has an adverse effect on health. ${ }^{5}$

Dayak Onion (Eleutherinepalmifolia) is a Dayak tribe plant based on empirical experience of people in Kalimantan, Indonesia that can be used to treat heart disease and diarrhea. Dayak Onions can also cure mental stress, heart problems, and tumors. ${ }^{6}$ Based on research by Febrinda et al. (2013), the ethanol extract of dayak onion tuber had phytochemical content as an antioxidant including triterpenoids, flavonoids, phenolics, alkaloids and tannins. ${ }^{7}$

The DPPH method has been widely applied to various samples such as fruit, vegetables or seeds. ${ }^{8,9}$ The principle of this method is that hydrogen atoms from an antioxidant compound will make the DPPH solution colorless which can be measured using a UV-Vis spectrophotometer due to the formation of reduced DPPH. ${ }^{10,11}$ Therefore, this research aimed to determine the active fraction of Dayak Onion (Eleutherinepalmifolia) which possesses antioxidant activity.

Rasayan J. Chem., 12(3), 1340-1346(2019)

http://dx.doi.org/10.31788/RJC.2019.1235264

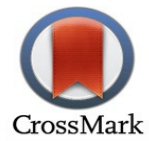


The Brine Shrimp Lethality Test (BSLT) method uses experimental animals, namely A. salina Leach larvae. Toxicity test where the toxic effect of a compound can be seen quickly, for 24 hours after being given a test dose, this method is called the BSLT method. The selection of the BSLT method is easy, fast, inexpensive and sufficiently reproductive. Some compound bioactivity that has been successfully isolated and monitored by BSLT activity shows that there is a correlation in a specific anticancer test. ${ }^{11-13}$

\section{Materials and Equipment}

\section{EXPERIMENTAL}

The equipment used in this study included glassware, analytical balance, test tube rack, spatula, UV lamp, GF 254 silica gel plate, micropipette, chromatography chamber, cover glass for chamber and UV-spectrophotometer 1800 (Shimadzu). Materials used were including aluminum foil, filter paper, ethanol $95 \%$, distilled water, iron (III) chloride, potassium hydroxide, magnesium powder, butanol, dragendorf reagent, mayer reagent, Lieberman-Bouchard at reagent, glacial acetic acid. All chemical compounds were obtained from sigma Aldrich. Moreover, extracts and fractions of Dayak onion bulbs, vitamin C and DPPH (1,1-Diphenyl-2-Pikrilhidrazil) were obtained from the Laboratory of Pharmacy Analysis at the Samarinda Pharmacy Academy, Indonesia.

\section{Extraction and Fractionation}

The maceration extraction method was carried out using $95 \%$ of the ethanol solvent. As many as 200 grams of simplified Dayak onion (EleutherinebulbosaUrb.) which has been sieved with 40 mesh sieves was macerated with 2 liters of $95 \%$ of ethanol solvent (1:10) slowly while keeping the stirring process until the solvent soaks all dayak onion tuber powder. Then, it was macerated for 2 hours and soaked up to 24 hours and filtered using filter paper. The Re-maceration process was performed twice. The macerate that has been produced was then concentrated with a rotary evaporator at $500 \mathrm{C}$ and then evaporated in the water until a thick extract was obtained. Dayak onion tuber extract was then fractionated by a solid-liquid method using multilevel n-hexane, chloroform and ethyl acetate solvents. The Fractionation was done by adding $\mathrm{n}$-hexane solvent to the extract with a ratio of 1:10 which was divided into 5 stirring times using the aid of a magnetic stirrer for \pm 10 minutes, then the filtrate was separated. The residue was fractionated again using sequential chloroform and ethyl acetate solvents with the same procedure. After that, the filtrate was applied using a water bath until a thick fraction was obtained, then the yield was calculated. Finally, the total ethanol extract, n-hexane fraction, chloroform fraction, ethyl acetate fraction, and a residual fraction (ethanol fraction) were obtained.

\section{Phytochemical Screening}

Phytochemicalscreening is an initial analysis conducted to determine the type of secondary metabolites found in Dayak onion tuber. Several tests conducted were alkaloid, flavonoid, saponin, tannin, steroid/ triterpenoid and quinone test

\section{Antioxidant Activity Test by Using UV-Visible Spectrophotometry}

This test was performed to determine the activity of Dayak onion as an antioxidant. It was started by preparing $40 \mathrm{ppm}$ of DPPH solution and determining its wavelength. Then, a series of vitamin $\mathrm{C}$ solutions were prepared with the concentration of 2, 4, 6, 8 and $10 \mathrm{ppm}$ respectively. After that, these solutions were added with DPPH and their absorbance value was measured. Next, the Dayak onion was extracted and added with DPPH. Finally, its absorbance was measured as well. All data from the determination of absorption curves of DPPH $0.004 \%$ added with a series of vitamin C concentrations and DPPH $0.004 \%$ absorption curve added with a series of preparation test concentrations. ${ }^{14}$

The calculation formula used is the general formula of absorbance, namely:

$$
\% \text { inhibition }=\frac{\text { Blank Absorbance }- \text { Sample Absorbance }}{\text { Blank Absorbance }} \times 100 \%
$$


RASĀYAN J. Chem.

Vol. 12 | No. 3 |1340 - 1346| July - September | 2019

Furthermore, in order to categorize the antioxidant level, a categorization from (Molyneux, 2004) is used ${ }^{15}$

Table-1: Antioxidant Categorization

\begin{tabular}{c|c}
\hline $\mathrm{IC}_{50}$ Value $(\mu \mathrm{g} / \mathrm{mL})$ & Antioxidant Activity \\
\hline$<50$ & Very High \\
\hline $50-100$ & High \\
\hline $100-150$ & Medium \\
\hline $150-200$ & Low \\
\hline$>200$ & Very Low \\
\hline
\end{tabular}

BSLT Testing

Making Artificial Sea Water (ALB)

Artificial sea water was prepared by dissolving 15 gr of sodium chloride in $1 \mathrm{~L}$ of distilled water. ${ }^{16}$

Hatching of $A$. salina Leach eggs

Shrimp eggs were hatched about 36-48 hours before toxicity testing. A clear or transparent cone-shaped container was used for hatching shrimp eggs, and then artificial sea water $(\mathrm{pH} \mathrm{8-9)}$ was added. The container was illuminated with lamp light 40 Watts to warm the temperature so that the hatching temperature of $25^{\circ} \mathrm{C}-31^{\circ} \mathrm{C}$ was maintained and the hatching process was stimulated using an aerator. As many as 50-150 mg of A. salina Leach eggs were washed first, was sprinkled and soaked in a container containing distilled water for 1 hour. After that, in a container containing $500 \mathrm{~mL}$ of artificial sea water, the aerator was ignited. The eggs of A. salina Leach were left for 36-48 hours until they hatch into mature nauplii and were ready for use in the experiment. The eggs would hatch in 18-48 hours and will move naturally towards bright areas so that the shrimp larvae were separated from the egg shell. Healthy larvae are phototropic and ready to be used as test animals at the age of 36-48 hours. Larvae are separated from their eggs by pipette into vials containing artificial sea water. ${ }^{16}$

\section{Preparing the Test Solution}

Vials were prepared for each group based on the concentration rating with each of them then provided with 8 vials and replicated 3 times. In this toxicity test, a stock (main) solution was made. Tests were carried out using test solutions made with concentrations of $0 \mathrm{ppm}$ (negative control), $40 \mu \mathrm{g} / \mathrm{mL}, 80$ $\mu \mathrm{g} / \mathrm{mL}, 160 \mu \mathrm{g} / \mathrm{mL}, 320 \mu \mathrm{g} / \mathrm{mL}$, and $640 \mu \mathrm{g} / \mathrm{mL}$ in artificial sea water. Each vial that was filled with a sample with a volume of $10 \mathrm{ml}$ was filled with 20 larvae of A. salina Leach and added one drop of yeast suspension $(0.6 \mathrm{mg} / \mathrm{mL})$ as food. ${ }^{15}$ The negative control test (blank) was given the same treatment as the test solution but without extract. The vials were placed under lighting with 40 Watt lights. The number of A. salina Leach larvae that died in each vial for 24 hours was calculated manually. Observations were made for 24 hours and the level of toxicity was obtained by counting the number of dead larvae, ie if the shrimp larvae did not show movement for several seconds of observation. ${ }^{17}$

Table-2: Toxicity Level(LC50) $)^{15}$

\begin{tabular}{c|c}
\hline $\mathrm{LC}_{50}$ Value $(\mu \mathrm{g} / \mathrm{mL})$ & Toxicity Level \\
\hline $0-250$ & Very toxic \\
\hline $250-500$ & Toxic \\
\hline $500-750$ & Less Toxic \\
\hline $750-1000$ & Not Toxic \\
\hline
\end{tabular}

\section{Results of Determination}

\section{RESULT AND DISCUSSION}

The determination confirmed that the plant used wasdayak onion (Eleutherinepalmifolia). Based on the results of the Plant Anatomy and Systematics Laboratory, Faculty of Mathematics and Natural Sciences, Mulawarman University, Samarinda. The results of the determination showed that the tuber used in the study was true of dayak onion tuber (EleutherinebulbusaUrb.) From the Iridaceae family.

\section{Phytochemical Screening}

The secondary metabolite groups testing were aimed to determine the presence of secondary metabolites 
RASĀYAN J. Chem.

Vol. 12 | No. 3 |1340 - 1346| July - September | 2019

in natural material samples. The results of phytochemical screening tests on total ethanol extract (ET), n-hexane $(\mathrm{H})$ fraction, chloroform $(\mathrm{K})$ fraction, ethyl acetate fraction (EA) and ethanol (E) fraction on dayak onion tuber can be seen in Table-3.

Table-3: Photochemical Screening Test Result

\begin{tabular}{c|c|c|c|c|c|c}
\hline \multirow{2}{*}{ Compounds } & \multirow{2}{*}{ Test } & \multicolumn{4}{|c}{ Result } \\
\cline { 2 - 6 } & & Et & H & Ch & Ea & E \\
\hline \multirow{2}{*}{ Alkaloid } & Mayer & - & - & + & - & - \\
\cline { 2 - 6 } & Bouchardat & + & + & + & + & + \\
\cline { 2 - 6 } & Dragendorf & + & - & + & + & + \\
\hline Flavonoid & HCL(c), Mg powder. Amyl alcohol & + & + & + & + & + \\
\hline Saponin & HCL 2N & - & - & - & - & - \\
\hline Tannin & FeCl 1\% & + & - & - & + & - \\
\hline Steroid & $\mathrm{N}-H e x a n e$, acetic acid anhydrate, $\mathrm{H}_{2} \mathrm{SO}_{4}(\mathrm{c})$ & - & - & - & - & - \\
\hline Quinone & $\mathrm{NaOH} \mathrm{1N}$ & + & - & + & - & + \\
\hline
\end{tabular}

Notes:

$(-) \quad=$ Negative result

$(+) \quad=$ Positive result

Et $\quad=$ Total ethanol extract

$\mathrm{H} \quad=$ n-hexane fraction

$\mathrm{Ch}=$ Chloroform fraction

$\mathrm{Ea} \quad=$ Ethyl acetate fraction

$\mathrm{E} \quad=$ Ethanol fraction

Groups of compounds which are suspected of being potential antioxidants in the ethanol extract of Dayak Onion bulbs are including flavonoids and quinones. Flavonoid compounds in their structure contain hydroxyl groups that can donate hydrogen atoms to free radicals, so that flavonoid compounds have the potential as antioxidants. Flavonoids are reducing compounds that can inhibit many oxidation reactions. Moreover, flavonoids have the ability as antioxidants since they are able to transfer an electron to free radical compounds as well as quinones. ${ }^{18}$

\section{Antioxidant Test Using a UV-Visible Spectrophotometer}

The antioxidant activity test in this study used the DPPH (2,2-Difenyl-1-Pikrilhidrazil) method. Tests were carried out at the Pharmacy Laboratory ofAkademiFarmasiSamarinda, Indonesia. The test results can be seen in Table-4.

Table-4: Antioxidant Activity Test Result

\begin{tabular}{|c|c|c|c|c|c|c|c|}
\hline \multirow[b]{2}{*}{ Test Group } & \multirow{2}{*}{$\begin{array}{l}\text { Concentration } \\
\text { (ppm) }\end{array}$} & \multicolumn{2}{|c|}{ Absorbance } & \multirow[b]{2}{*}{$\%$ Inhibition } & \multirow{2}{*}{$\begin{array}{l}\text { Linear Regression } \\
\text { and } \mathrm{R}^{2} \text { Value }\end{array}$} & \multirow[b]{2}{*}{$\mathrm{IC}_{50}(\mathrm{ppm})$} & \multirow[b]{2}{*}{ Category } \\
\hline & & Blank & Sample & & & & \\
\hline \multirow{5}{*}{ Vitamin C } & 2 & \multirow{5}{*}{0.5214} & 0.4936 & 5.332 & \multirow{5}{*}{$\begin{array}{c}y=5.7106 x- \\
6.2332 \\
R^{2}=0.9987\end{array}$} & \multirow{5}{*}{9.847} & \multirow{5}{*}{ Very High } \\
\hline & 4 & & 0.4377 & 16.053 & & & \\
\hline & 6 & & 0.3717 & 28.711 & & & \\
\hline & 8 & & 0.3171 & 39.183 & & & \\
\hline & 10 & & 0.2804 & 46.222 & & & \\
\hline \multirow{3}{*}{$\begin{array}{l}\text { Total } \\
\text { Ethanol } \\
\text { Extract }\end{array}$} & 25 & \multirow{3}{*}{0.7745} & 0.6886 & 11.091 & \multirow{3}{*}{$\begin{array}{c}\mathrm{y}=0.2394 \mathrm{x}+ \\
4.7593 \\
\mathrm{R}^{2}=0.9688\end{array}$} & \multirow{3}{*}{188.975} & \multirow{3}{*}{ Low } \\
\hline & 50 & & 0.6235 & 19.496 & & & \\
\hline & 100 & & 0.5891 & 23.938 & & & \\
\hline
\end{tabular}

1343 
RASĀYAN J. Chem.

Vol. 12 | No. 3 |1340 - 1346| July - September | 2019

\begin{tabular}{|c|c|c|c|c|c|c|c|}
\hline & 200 & & 0.3541 & 54.280 & & & \\
\hline \multirow{5}{*}{$\begin{array}{l}n \text {-Hexane } \\
\text { Fraction }\end{array}$} & 12.5 & \multirow{5}{*}{0.6854} & 0.6783 & 1.036 & \multirow{5}{*}{$\begin{array}{c}\mathrm{y}=0.1381 \mathrm{x}- \\
0.8037 \\
\mathrm{R}^{2}=0.9853\end{array}$} & \multirow{5}{*}{367.87} & \multirow{5}{*}{ Very Low } \\
\hline & 25 & & 0.6569 & 4.158 & & & \\
\hline & 50 & & 0.6577 & 4.041 & & & \\
\hline & 100 & & 0.5946 & 13.248 & & & \\
\hline & 200 & & 0.5002 & 27.021 & & & \\
\hline \multirow{4}{*}{$\begin{array}{l}\text { Chloroform } \\
\text { Fraction }\end{array}$} & 5 & \multirow{4}{*}{0.6555} & 0.583 & 11.060 & \multirow{4}{*}{$\begin{array}{c}\mathrm{y}=2.187 \mathrm{x}+ \\
5.5616 \\
\mathrm{R}^{2}=0.9627\end{array}$} & \multirow{4}{*}{20.290} & \multirow{4}{*}{ Very High } \\
\hline & 10 & & 0.475 & 27.536 & & & \\
\hline & 20 & & 0.271 & 58.658 & & & \\
\hline & 40 & & 0.072 & 89.016 & & & \\
\hline \multirow{5}{*}{$\begin{array}{c}\text { Ethyl } \\
\text { Acetate } \\
\text { Fraction }\end{array}$} & 12.5 & \multirow{5}{*}{0.6739} & 0.6507 & 3.442 & \multirow{5}{*}{$\begin{array}{c}\mathrm{y}=0.2205 \mathrm{x}+ \\
1.8105 \\
\mathrm{R}^{2}=0.9942\end{array}$} & \multirow{5}{*}{218.550} & \multirow{5}{*}{ Very Low } \\
\hline & 25 & & 0.6303 & 6.460 & & & \\
\hline & 50 & & 0.5749 & 14.690 & & & \\
\hline & 100 & & 0.5076 & 24.679 & & & \\
\hline & 200 & & 0.3692 & 45.215 & & & \\
\hline \multirow{4}{*}{$\begin{array}{l}\text { Ethanol } \\
\text { Fraction }\end{array}$} & 25 & \multirow{4}{*}{0.7745} & 0.6986 & 9.800 & \multirow{4}{*}{$\begin{array}{c}\mathrm{y}=0.2791 \mathrm{x}+ \\
5.2584 \\
\mathrm{R}^{2}=0.9844\end{array}$} & \multirow{4}{*}{160.306} & \multirow{4}{*}{ Low } \\
\hline & 50 & & 0.6226 & 19.613 & & & \\
\hline & 100 & & 0.4893 & 36.824 & & & \\
\hline & 200 & & 0.3141 & 59.445 & & & \\
\hline
\end{tabular}

Based on Table-4, it can be seen that chloroform fraction has an IC50 value of 20.290 ppm (very strong category) is the best activity compared to other fractions. The principle of the radical capture method is the measurement of free radical capture in solvents such as ethanol/methanol at room temperature by a compound that has antioxidant activity. DPPH compounds are stable free radicals that can react with hydrogen atoms to form stable reduced DPPH. A compound can be said to have antioxidant activity if it is able to donate hydrogen atoms which are marked by purple changes to yellow. ${ }^{15}$

DPPH color immersion occurs because of the presence of compounds that can provide hydrogen radicals to DPPH radicals so that they are reduced to DPPH-H. ${ }^{15}$ TheDPPH reduction reaction can be seen in Fig.-1.<smiles>[R][C@H](C)ONc1cc([N+](=O)[O-])c(NN(c2ccccc2)c2ccccc2)c([N+](=O)[O-])c1</smiles>

Fig.-1:The DPPH Reduction from a Free Radical Compound

The absorbance measurements were carried out by a visible spectrophotometer at a wavelength of 517.3 $\mathrm{nm}$. Antioxidant activity is expressed by IC50 (inhibitory concentration) which shows the concentration of antioxidant samples that can inhibit or reduce the higher antioxidant activity. In other words, IC50 as the concentration of antioxidant compounds causes $50 \%$ loss of free radical activity (DPPH). The smaller the IC50 value means the higher antioxidant activity. ${ }^{15}$ Based on Figure 2, it shows that Chloroform Fraction of DayakOnion Bulbs has an IC50 value of 20.290 ppm which is categorized as a very strong antioxidant while vitamin $\mathrm{C}$ as a comparison, has $9.847 \mathrm{ppm}$ of IC50 value (a very strong antioxidant). 
This radical capture process was through the mechanism of taking hydrogen atoms from antioxidant compounds by free radicals, so that free radicals capture an electron from antioxidants. The synthetic-free radicals used are DPPH. DPPH compounds react with antioxidant compounds through capturing hydrogen atoms from antioxidant compounds to obtain electron pairs. ${ }^{18}$ The compound that has the potential as an antioxidant in the Chloroform Fraction is considered to be flavonoids. Flavonoid compounds contain hydroxyl groups which can donate hydrogen atoms to free radicals, so that flavonoids have the potential as antioxidants. Flavonoids are reducing compounds that can inhibit many oxidation reactions. Also, flavonoids have the ability as an antioxidant since they can transfer an electron to free radical compounds, where $\mathrm{R} \bullet$ is a free radical compound, $\mathrm{Fl}-\mathrm{OH}$ is a flavonoid compound while $\mathrm{Fl}-\mathrm{OH} \bullet$ is a flavonoid radicals. ${ }^{19}$

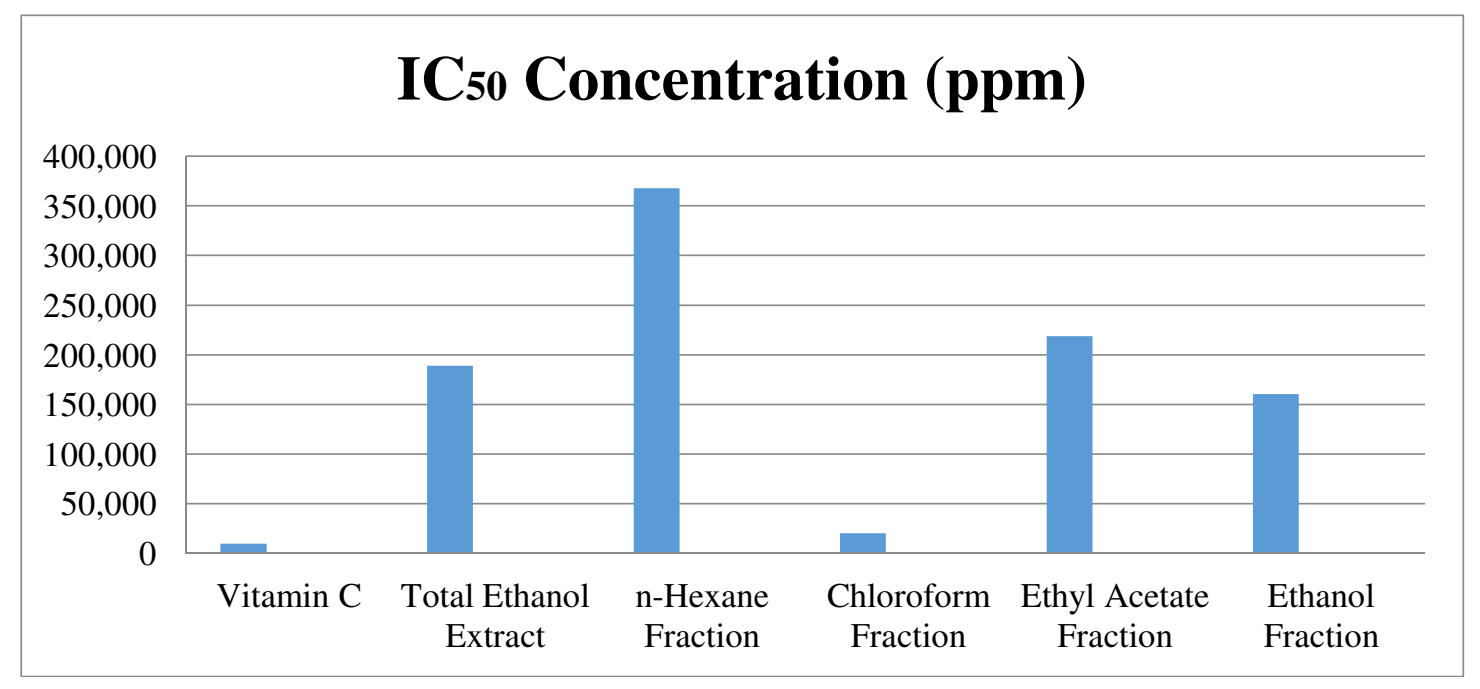

\section{BSLT Testing}

Fig.-2: $\mathrm{IC}_{50}$ (Inhibitory Concentration) value of Dayak Onion (Eleutherinepalmifolia)

BSLT testing is an acute toxicity test conducted to determine the activity contained in the Dayak onion fraction within 24 hours using the BSLT method to determine the toxic effect after dosing. The concentration orientation test resulted in the percentage of larval deaths in the range of $5-100 \%$ and the test concentrations were $40 \mathrm{ppm}, 80 \mathrm{ppm}, 160 \mathrm{ppm}, 320 \mathrm{ppm}$ and $640 \mathrm{ppm}$ respectively. The results of BSLT shows that the toxicity level is categorized as less toxic (Table-5).

Table-5: $\mathrm{LC}_{50}$ value of Choloroform Fraction

\begin{tabular}{|c|c|c|c|c|c|c|c|c|}
\hline Fraction & Concentration & $\begin{array}{l}\text { Concentration } \\
\text { Log }\end{array}$ & $\begin{array}{l}\text { Death } \\
\text { Count }\end{array}$ & $\begin{array}{c}\text { Death } \\
\text { Percentage }\end{array}$ & Probit & $\begin{array}{c}\text { Linear } \\
\text { Regression }\end{array}$ & $\mathrm{IC}_{50}$ & Toxicity \\
\hline \multirow{5}{*}{$\begin{array}{l}\text { Chloroform } \\
\text { Fraction }\end{array}$} & 40 & 1.602 & 1 & 5 & 3.36 & \multirow{5}{*}{$\begin{array}{l}\mathrm{y}=1.392 \mathrm{x}+ \\
1.21 \quad \mathrm{R}^{2}= \\
0.9848\end{array}$} & \multirow{5}{*}{527.229} & \multirow{5}{*}{ Less toxic } \\
\hline & 80 & 1.903 & 3 & 15 & 3.96 & & & \\
\hline & 160 & 2.204 & 5 & 25 & 4.33 & & & \\
\hline & 320 & 2.505 & 7 & 35 & 4.61 & & & \\
\hline & 640 & 2.806 & 13 & 55 & 5.13 & & & \\
\hline
\end{tabular}

CONCLUSION

Based on the results of the research it can be concluded that the Dayak onion in chloroform fraction (Eleutherine palmifolia) has very strong antioxidant activity with IC50 of $20.29 \mathrm{ppm}$. In addition, the BSLT test of the chloroform fraction produced an LC50 value of 527.229 (medium category). 
RASĀYAN J. Chem.

Vol. 12 | No. 3 |1340 - 1346| July - September | 2019

\section{ACKNOWLEDGMENT}

Authors would like to thank the Directorate of Research and Community Service of the Directorate General of Strengthening Research and Development at the Ministry of Research, Technology and Higher Education, Ministry of Research, Technology and Higher Education of Indonesia for funding this research via The PKPT Scheme (Collaborative Research between Universities with contract numbers: 560/CONTRACTS/K11/KM/2018.

\section{REFERENCES}

1. M. I. Alkhalf, W. S. Alansari, E. A. Ibrahim, M. E. A. Elhalwagy, J. King Saudi Univ., Science xxx (2018), DOI:10.1016/j.jksus.2018.10.010

2. T. Okselni, A. Santoni, A. Dharma, M. Efdi, Rasayan J. Chem., 12(1), 146(2019), DOI: 10.31788/RJC.2019.1215019

3. R. M. S. Al-Hadhrami, M. A. Hossain, Egyptian J. Basic Appl. Sci., 3, 329 (2016), DOI: 10.1016/j.ejbas.2016.08.001

4. B. Pan, H. Li, D. Lang, B. Xing, Environ. Pollut., 248, 320 (2019), DOI: 10.1016/j.envpol.2019.02.032

5. K. Febriani, Uji Aktivitas Antioksidan Ekstrakdan Fraksi Daun, Cocculusorbiculatus (L.) DC dengan Metode DPPH dan Identifikasi Golongan Senyawa Kimia Dari Fraksi Yang Aktif”. Thesis. Depok: Universitas Indonesia (2012)

6. E. S. Syamsul, Supomo, Majalah Obat Tradisional UGM, 19(3), (2014)

7. A. E. Febrinda, et al., Intl. Food Res. J.,21(4), 1405 (2014)

8. S. M. Sinaga, S. Sudarmi, I. Iksen, K. Kevin, M. P. Sari, Rasayan J. Chem., 11(4), 1604 (2018). DOI:10.31788/RJC.2018.1144067

9. I. Hamloui, R. Bencheraiet, R. Bensegueni, M. Bencharif, J. Mol. Struc., (2018), DOI: 10.1016/j.molstruc.2017.11.118

10. A. Tonelli, A. Candiani, M. Sozzi, A. Zucchelli, R. Foresti, C. Dall'Asta, S. Selleri, A. Cucinotta, Sensors and Actuators: Chemical, 282, 559 (2019), DOI:10.1016/j.snb.2018.11.019

11. B. N. Meyer, N. R. Ferrigni, J. E. Putnam, L. B. Jacobsen, D. E. Nicholas, J. L. Mc Laughlin, Drug Information J.,45, 31 (1982), DOI:10.1055/s-2007-971236

12. P. Tanamatayarat, Asia Pacific J. Trop. Biomed., 6(12), $1050 \quad$ (2016), DOI:10.1016/j.apjtb.2016.10.001

13. T. L. G. Lemos, L. L. Machado, J. S. N. Souza, A. M. Fonseca, J. L. Maia, O. D. L. Pessoa, Fitoterapia, 77, 443 (2006), DOI:10.1016/j.fitote.2006.04.008

14. Supomo, E. S. Syamsul, N. Manurung, Jurnal Ilmiah Sehat Bebaya, 1(2), (2017).

15. P. Molyneux, J. Sci. Technol., 26(2), 211 (2004).

16. Harmita, M. Radji, Analisis Hayati. Jakarta: Penerbit Buku Kedokteran (2008).

17. Priyanto, Toksikologi Mekanisme Terapi Antidotumdan Penilaian Resiko, Jakarta: Lembaga Studidan Konsultasi Farmakologi (2009).

18. E. A. Ridho,. "Uji Aktivitas Antioksidan Ekstrak Metanol Buah Lakum (Cayratiatrifolia) dengan Metode DPPH (2,2-Difenil-1-Pikrilhidrazil)". Thesis. Pontianak: Universitas Tanjungpura (2013).

19. C. Kandaswami, E. Middleton, Flavonoids as antioxidant, In F. Shahidi (Ed). Natural Antioxidant Chemistry, Health Effects and Applications. Champaign Illions: AOCS Press (1997).

[RJC-5264/2019] 